\title{
Development of equity regulations in the Basel framework
}

\author{
Günter Hofbauer, ${ }^{1}$ Aleksandra Nocoń, ${ }^{2}$ Monika Klimontowicz ${ }^{3}$ \\ ${ }^{1}$ Prof. Dr. rer. Pol., Technische Hochschule Ingolstadt, Germany \\ e-mail: guenter.hofbauer@thi.de \\ ${ }^{2} \mathrm{PhD}$, Department of Banking and Financial Markets, University of Economics in Katowice \\ e-mail: aleksandra.nocon@ue.katowice.pl \\ ${ }^{3} \mathrm{PhD}$, Department of Banking and Financial Markets, University of Economics in Katowice \\ e-mail:mklimontowicz@ue.katowice.pl
}

KEYWORDS equity regulations, capital adequacy, Capital Adequacy Ratio, Basel Committee on Banking Supervision, risk

ABSTRACt Purpose - the main aim of the study is to present the evolution of the regulations of the Basel Committee on Banking Supervision, paying particular attention to changes in equity regulations, initiating national and international standards for capital security of banks.

Methodology - in the empirical part we show the equity rate of banks changing over the years from 2008 or 2011 until 2015/2016.

Findings - the global financial crisis has revealed the need to improve methods of risk assessment and management in banking institutions. In fact, stability of a bank determines the stability of whole financial system. Therefore, the Basel Committee on Banking Supervision stands in the face of adapting the existing requirements, which aimed at maintaining safety of banks' capital. However, it should be noted that despite regular updating of the banks' equity regulation, towards their adaptation to the changing macroeconomic conditions, the situations of bankruptcy and insolvency of banks are observed.

Value - capital is a basic value, which is the subject of assessment from the banks' prudential standards point of view. It performs particular functions - guarantees safety, absorbs potential losses, and supports the maintenance of institutions stability, guaranteeing their further development. The key objective of equity regulations is to ensure safety of functioning of individual banks and the whole financial system, of which banks are the most important element.

\section{Ewolucja regulacji kapitałowych Bazylejskiego Komitetu Nadzoru Bankowego}

KEYWORDS $\quad$ regulacje kapitałowe, adekwatność kapitałowa, współczynnik adekwatności kapitałowej, Bazylejski Komitet Nadzoru Bankowego, ryzyko

Streszczenie Cel-ukazanie ewolucji regulacji Bazylejskiego Komitetu Nadzoru Bankowego ze zwróceniem szczególnej uwagi na przemiany regulacji kapitałowych, inicjujące krajowe i międzynarodowe standardy zabezpieczenia kapitałowego banków.

Metodyka badania - badania empiryczne koncentrują się na prezentacji zmian wielkości wskaźników adekwatności kapitałowej w latach 2008/2011-2015/2016.

Wynik - globalny kryzys finansowy unaocznił potrzebę doskonalenia metod pomiaru i zarządzania ryzykiem w instytucjach bankowych. Stabilność banku determinuje bowiem stabilność całego system 
finansowego. Bazylejski Komitet Nadzoru Bankowego staje więc w obliczu adaptacji istniejących wymogów, które mają sprzyjać właściwemu zabezpieczeniu kapitałowemu banków. Należy jednak podkreślić, że pomimo systematycznej aktualizacji regulacji kapitałowych banków w kierunku ich adaptacji do zmieniających się uwarunkowań makroekonomicznych, zdarzają się sytuacje upadłości oraz niewypłacalności banków.

Wartość - kapitał jest podstawową wielkością, będącą przedmiotem oceny z punktu widzenia norm ostrożnościowych banków. Pełni on szczególną funkcję - gwarantuje bezpieczeństwo, absorbuje ewentualne straty oraz wspiera utrzymanie stabilności instytucji, gwarantując jego dalszy rozwój. Kluczowym celem regulacji kapitałowych jest więc zapewnienie bezpieczeństwa funkcjonowania pojedynczych banków oraz całego systemu finansowego, którego najistotniejszym ogniwem są właśnie banki.

\section{Introduction}

There is a necessity for a regulatory framework to restrain uninhibited power of free capitalistic markets. Especially in the banking sector there is a strong imperative for regulation to protect effective operation to supply real economy with money. The occurrence of the last financial crisis disclosed us very impressively that the existing regulations have not been effective enough. There is a high complexity of influencing factors in global economy and the regulations are always lagging behind. New kinds of risk have been revealed and the regulatory response was immediate in terms of Basel III.

The Basel Committee on Banking Supervision elaborated a new issue of regulations in terms of Basel III. Herein they developed two adaptations of capital requirement and transformed in EU law with Capital Requirement Directive (CRD III, Directive 2010/76/EU) and the proposed CRD IV and Capital Requirements Regulation. The scope is to strengthen prudential banking rules. The core of the matter is to require more and a higher quality of capital. This will not only have an impact on banks, it will also affect credit seeking companies, because risk will be considered much more. Higher capital charges will be required for market activities with higher risk.

The new regulations of Basel III shall contribute to a better financial stability, stronger business models of banks and more reliable balance sheets. This calls for a closer look on the business model of the borrowers, especially on the risks taken in the business. This facilitates the calculation of a risk adequate interest rate.

In this article we show the development of equity regulations elaborated in the different stages of development of the Basel framework. In the empirical part we show an interesting outcome concerning the equity rate of banks.

\section{From the beginning of capital adequacy regulations}

Events that took place in the twentieth century fostered alternately different doctrines relating to the scope and scale of regulation of the banking sector. Supporters of "free banking" called for more loosening in regulatory discipline, believing in the ability of banking sector self-regulation and market supervision. In turn, their opponents pointed to the advantages of banks' strict regulations, by creating more and more restrictions and requirements for capital adequacy. 
Since the 30 s of the twentieth century, so since the Great Depression, prudential standards were gradually implemented, aimed at countering the threat of banking institutions' bankruptcy. At the beginning, there were set the guidelines regulating the scope of activity carried out by banks and prudential standards depending on the scale of this activity as well as risk exposure. A special role was attributed to the banks' own funds - as a non-repayable source of financing, enabling the absorption of losses and guaranteeing the fulfillment of claims for creditors in case of potential bank's insolvency. So that equity became a main axis of banks' prudential regulations (Marcinkowska, 2005).

In the late 80 s of the twentieth century with the growing importance of risk management and the need to regulate banking supervision, the Basel Committee on Banking Supervision developed innovative rules relating to the security of the banking system. Basel Committee is not a supervision authority, and its recommendations are not applicable legal standards. These are only recommendations for good practice that national authorities can implement to their legislation in the form of relevant law acts, adapting to financial system specificities. At the same time, due to the high authority of the Committee, they are recognized in many countries around the world as a basis of created legal acts.

In 1988 the Basel Committee has introduced a capital measurement system, presented in the document known as Basel Capital Accord (Basel I). The most important element became a synthetic measure of the Capital Adequacy Ratio (CAR) (Basel..., 1988). This indicator, also known as Cooke ratio (Total Capital Ratio - TCR, Capital to Risk Weighted Assets Ratio - CRAR), determines how much capital a bank must hold so its activity is safe (see more: Nocoń, 2015, pp. 224-225). Initially, Capital Adequacy Ratio was referred only to credit risk, and therefore was defined as a relation between bank's capital base (own funds, consisting of Tier I capital, as a basis to cover losses, and Tier II capital as supplementary capital for a bank) to risk-weighted assets (Iwanicz-Drozdowska, 2012a, pp. 136-137).

$$
C A R_{1}=\frac{c_{\text {tier I }}+c_{\text {tier II }}-c_{\text {deduction }}}{r_{\text {cred }}} \geq 8 \% \text {, }
$$

wherein: $\quad r_{\text {cred }}=r_{b s}+r_{\text {obs }}$,

where:

$C A R_{1}$ - Capital Adequacy Ratio,

$c_{\text {tier I }}$ - basic funds (core capital, basic equity) - Tier I capital,

$c_{\text {tier II }}-$ supplementary funds - Tier II capital,

$c_{\text {deduction }}-$ positions which reduce the total amount of funds,

$r_{\text {cred }}-$ exposure to credit risk (risk-weighted assets),

$r_{b s} \quad-$ exposure to credit risk on balance sheet items,

$r_{\text {obs }}-$ exposure to credit risk on off-balance sheet items.

Basel I required that the capital adequacy ratio cannot be lower than $8 \%$ (Iwanicz-Drozdowska, 2012a, pp. 132-135). It also defined four asset classes and four non-balance sheet liabilities classes, by assigning them risk weights $(0,20,50$ and 100\%). An important advantage of this approach was simplicity, which was also a main basis of criticism, because the assets were equally 
treated in the same group, without the possibility of varying the level of risk (Marcinkowska, 2010, p. 47).

However, changing environment of the banking sector, dynamic development of financial markets, high volatility of prices on the financial markets, orientation only on credit risk, and in particular the criticism of the oversimplified measurement in Basel I, led to the need to include in the measurement of capital adequacy, in addition to credit risk, also other kinds of risk, like: price (market) risk and operational risk. The work on the improvement of the Basel Agreement was revealed in 2004 (after six years of preparation, analysis and discussions), presenting its new framework known as Basel II - The New Basel Capital Accord (Basel..., 2004). In June 2006 revised and improved version of the concept of Basel II was published (Basel..., 2006). Its main foundation became the concept of economic capital, defined as the minimum value of own funds, which secures all unexpected losses, taking into account the bank's preferences in terms of the accepted level of risk (Adamowicz, 2005). Additionally, a third category of capital was introduced - Tier III capital (available to cover market risk). Basel II took into consideration a proposal of measuring capital adequacy, which was based on three complementary pillars (Iwanicz-Drozdowska, 2012a, pp. 135-144):

1. Pillar I - consists of setting the minimum requirements for capital adequacy, including credit risk, market risk and operational risk.

2. Pillar II - giving supervision authorities the additional task of assessing, whether the own funds, held by a bank, are sufficient in relation to the scale and risk profile of its business.

3. Pillar III - applies to market discipline, performed by market participants, assessing bank's risk on the basis of obtained information.

The first pillar indicated the minimum capital requirements. The New Basel Capital Accord maintained previously used definition of own funds and the minimum $8 \%$ level of Capital Adequacy Ratio. However, it implemented in its estimation - apart from credit risk - also market and operational risk. In place of previously used approach - equally for all banks - was recommended the system, which consisted of three methods, allowing banking institutions to choose the most appropriate for them: a simple approach (assigning weights depending on the assets credit quality), as well as intermediate and advanced approaches. Therefore, capital requirements according to Basel II are much more dependent on the risks incurred by a bank (Marcinkowska, 2010, p. 49). Furthermore, the New Basel Capital Accord allowed banks to use their own risk models (based on the VaR methodology) in estimation of market risk exposure.

The second pillar - the supervision review process - indicated that authorities responsible for banking supervision, should provide that each bank has implemented appropriate processes for capital adequacy evaluation, depending on risk assessment incurred by a bank.

In turn, the third pillar - market discipline - aimed to support personal monitoring through increasing the range of information disclosed by banks.

The capital adequacy ratio according to Basel II is defined as follows (Iwanicz-Drozdowska, 2012a, pp. 137-138; Marcinkowska, 2009, p. 106; Kopiński, 2008, p. 140):

$$
C A R_{I I}=\frac{c_{\text {tier I }}+c_{\text {tier II }}-c_{\text {deduction }}+c_{\text {tier III }}}{r_{\text {cred }}+12,5\left(r_{\text {mark }}+r_{\text {oper }}\right)} \geq 8 \% \text {, }
$$


where:

$c_{\text {tier III }}-$ third category of own funds - Tier III capital,

$r_{\text {mark }}$ - exposure to market risk,

$r_{\text {oper }}-$ exposure to operational risk.

Although Basel II was an important step in the field of prudential standards for banks in relation to Basel I, has had significant faults. Criticism of Basel II was related to Marcinkowska (2010, p. 50):

- difficulties in interpretation and application of the new regulations,

- its negative impact on developing countries,

- system domination by large banks,

- its pro-cyclicality.

It was also pointed to imperfections in the risk assessment methods, arguing that risk management is not only a science but it is an art. Moreover, capital adequacy assessment is done through risk models prism, which can be unreliable.

However, during implementation of the new recommendations, included in The New Basel Capital Accord in early 2007, the first symptoms of the global financial crisis occurred. It revealed many imperfections in risk management and existing supervisory regulations. Therefore, the international bodies, including the Basel Committee on Banking Supervision, were forced to revise the mandatory amount of banks' equity capital. All G-20 countries and 19 other nations asked for more sophisticated regulations. As a result, in the years of 2010-2011, the Basel III framework was presented, which will come into force successively until 2019.

\section{Equity regulations in Basel III}

In December 2010 the Basel Committee has published two documents, which significantly changed the rules of the banking institutions functioning after the global financial crisis of 2007-2008:

1. Basel III: A global regulatory framework for more resilient banks and banking systems.

2. Basel III: International framework for liquidity risk measurement, standards and monitoring.

These documents constitute a set of regulations known as Basel III, which complement the earlier recommendations of the Basel Committee - Basel I and Basel II. These changes were aimed at increasing the resistance of banking sector to financial shocks, in particular (Basel..., 2009):

- to promote the implementation of capital buffers that could be used during financial tensions,

- to strengthen the quality of bank capital,

- to introduce the leverage ratio as an additional control measure, complementary Basel II,

- to reduce cyclicality of the minimum capital requirements and promote a more prospective approach to the creation of reserves.

Basel III strengthens the existing equity requirements. It distinguishes two categories of capital in banks: Tier I and Tier II. Thereby, Tier III capital - introduced in The New Basel 
Capital Accord, disappeared in Basel III (Iwanicz-Drozdowska, 2012b, p. 48). Since the beginning of the Basel capital regulations, Tier I capital had the task of absorbing losses incurred by a bank. The higher the level of Tier I capital in relation to the scale of its operations, the higher the ability to survive periods of instability. However, after the experience of the global financial crisis, the Basel Committee has proposed tightening the rules for qualifying specific positions as core capital, to fully meet the requirements associated with the ability to cover losses. The amount of the capital adequacy ratio was left at the current level of $8 \%$. Nevertheless, in Basel III there has been made the distinction of own funds in (Iwanicz-Drozdowska, 2012b; Nocuń, 2016, pp. 210-212):

- Tier I capital, described as going concern capital,

- Tier II capital, described as gone concern capital.

This distinction between going and gone concern capital results from a situation in which the individual categories of capital may be used to cover losses. In the case of Tier I capital it is always possible, in the case of Tier II capital - only during bankruptcy or liquidation of a bank.

According to Basel III, Tier I capital consists of common equity Tier I (CET1) and additional Tier I capital. However, the main emphasis is on common equity Tier I, which includes (Basel..., 2010, p. 13):

- ordinary shares issued by a bank,

- the issue premium arising from the issuance of instruments classified as common equity Tier I,

- retained profits and other accumulated profits and disclosed reserves.

The above capital has to be considered as equity capital, according to national accounting standards. At the same time, it cannot be regarded as a liability for the purposes of determining the state of insolvency on the basis of balance sheet data, and must be specifically extracted in the balance sheet of banking institution. In turn, among the components of Tier II capital (supplementary funds) subordinated debt and reserves of general risk and surplus reserves for expected losses on the loan portfolio were qualified. These requirements are intended to prevent the assignment to own funds of such components, which are not adequately safe from the point of view of banks' capital adequacy. A kind of "failure" of hybrid instruments as a component of Tier I, required a tightening of the equity criteria (Iwanicz-Drozdowska, 2012b, p. 49).

In the existing regulations the relation between core and supplementary capital may amount to a maximum of $50 \%$. In turn, subordinated loans classified as Tier II capital could provide no more than $25 \%$ of core capital. This meant that the capital adequacy ratio calculated for Tier I could not be less than 4\%. Basel III has tightened existing recommendations, assigning a greater role of Tier I capital. Banks should therefore maintain capital adequacy ratios at the following levels (Basel..., 2010, p. 12):

- Common Equity Tier I ratio (CET1) $\geq 4,5 \%$,

- Tier I Capital ratio $\geq 6 \%$,

- Capital Adequacy Ratio (Tier I + Tier II) $\geq 8 \%$.

Despite the fact that the Basel Committee maintained the current level of capital adequacy ratio at a level of $8 \%$, but it also introduced two capital buffers:

- capital conservation buffer - which has protective character,

- countercyclical buffer - which has countercyclical character. 
Their aim is to increase the security of banks and banking sector, increasing requirements for the level of adequacy ratio, taking into account common equity Tier I. Capital conservation buffer refers to the level of capital protection at the level of individual bank (microeconomic approach), while the countercyclical buffer - at the level of the banking sector of a country (macroeconomic approach).

The protective buffer applies to all banks, regardless of jurisdiction, aiming to increase their resilience, expanding the capacity to absorb losses, as well as reducing the possibility of lowering the capital adequacy ratio below $8 \%$. The buffer limits possibilities of disposal of generated capital by banks through restrictions of paid dividends, buying its own shares or paying bonuses. Capital conservation buffer will appear in 2016 at a level of $0.625 \%$, in the following year it will increase to $1.25 \%$, after that to $1.875 \%$, and from the beginning of 2019 it will amount to $2.5 \%$ (Basel..., 2010, pp. 54-57).

The countercyclical buffer is an essential macro-prudential tool of the whole package of regulation. It has been addicted on the development of lending in a country. Its aim is to correct the growth rate of lending (cooling). It was added to the protective buffer. This buffer requires to maintain additional common equity Tier I in the range of 0 to $2.5 \%$ of risk weighted assets, depending on the assessment of the financial safety net institutions about the possibility of generating excessive systemic risk. The level of the buffer will vary with the level of protection buffer - in 2016 it will be at a maximum level of $0.625 \%$, gradually increasing the maximum value to $2.5 \%$. To determine the appropriate level of the countercyclical buffer, supervisory authorities should monitor banks' lending activities and other indicators related to systemic risk. This is to determine whether credit growth is not excessive and does not cause an increase of systemic risk (Basel..., 2010, pp. 57-60).

Figure 1. Changing equity structure from Basel I and II to Basel III

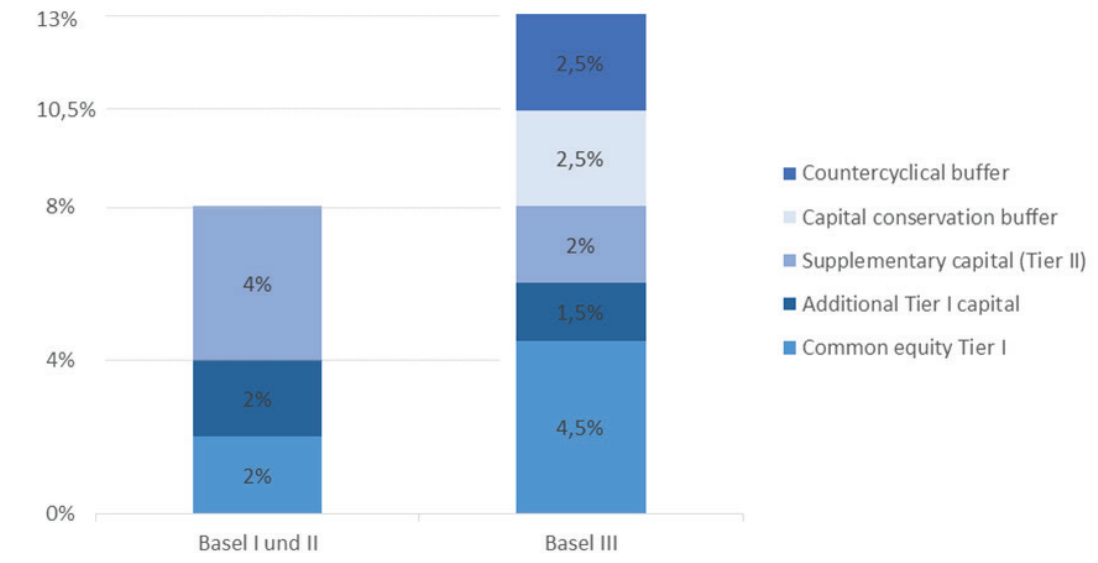

Source: Basel... (2010).

Basel III has caused a real increase in capital charges for banks (see Figure 1). The level of capital adequacy ratio is still equal to $8 \%$, however the sum of minimum Tier I ratio, minimum 
Tier II ratio and capital conservation buffer was set at a level of 10.5\%. Moreover, taking into account countercyclical buffer, equity requirements for banks increased to $13 \%$.

Figure 2. Basel III minimum equity requirements

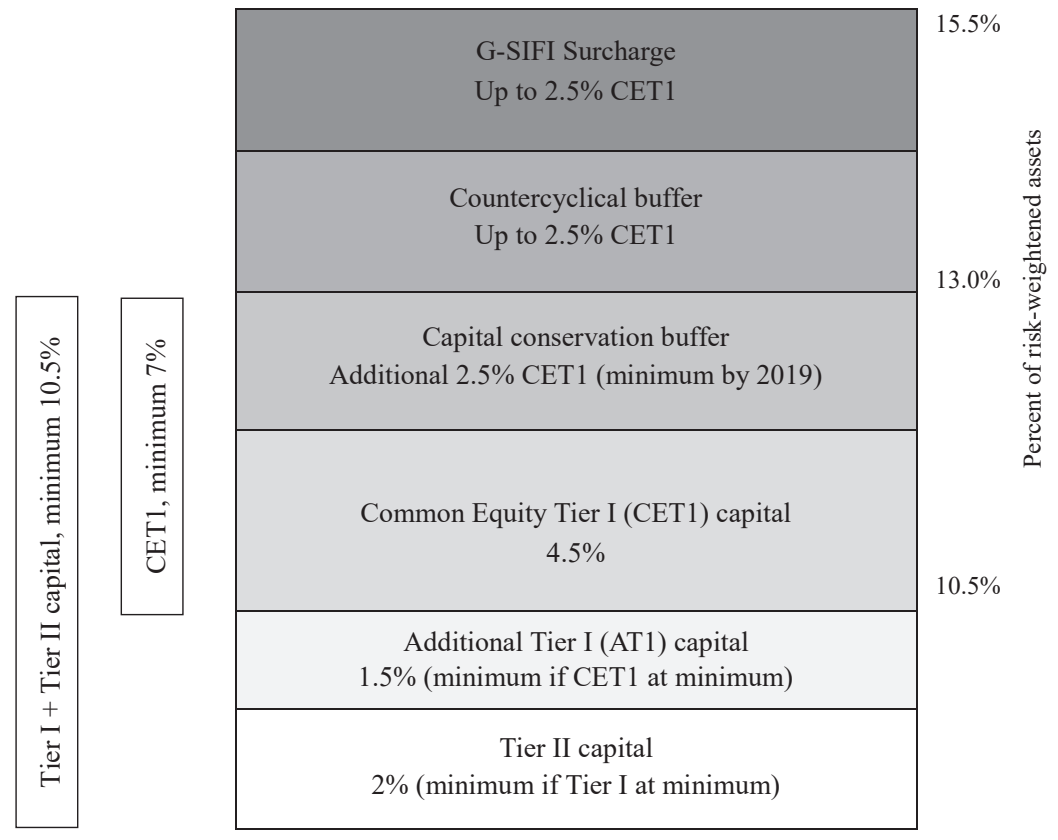

Source: own work based on Five years... (2013).

The new Basel recommendations also refer to Systematically Important Financial Institutions (SIFIs). Basel Committee defined that they should hold additionaly up to $2.5 \%$ of CET1. In this case, equity regulations for SIFIs increased to $15.5 \%$ (see Figure 2).

\section{Conclusion}

The global financial crisis has revealed the need to improve methods of risk assessment and management in banking institutions. In fact, stability of a bank determines the stability of whole financial system. Therefore, the Basel Committee on Banking Supervision stands in the face of adapting the existing requirements, which aimed at maintaining safety of banks' capital. However, it should be noted that despite regular updating of the banks' equity regulation, towards their adaptation to the changing macroeconomic conditions, the situations of bankruptcy and insolvency of banks are observed (Rojas-Suarez, 2001).

Some economists even argue that capital regulations negatively affect the behavior of banks, leading to an increase of undertaken risk (Blum, 1999). Thus, they are inefficient, encouraging banks to more risky operations in order to compensate lost benefits due to additional capital 
restrictions. Furthermore, in accordance with the Goodhart's law, it is expected that banks will seek to find gaps in the existing regulations, to circumvent stricter standards. Perhaps, it will be carried out through the creation of more and more innovative financial instruments and other methods of transferring risk to other sectors of the economy (Marcinkowska, 2010, p. 60).

\section{References}

Adamowicz, T. (2005). Practical aspects of the second pillar of the New Basel Capital Accord. Safe Bank, 2.

Basel Committee on Banking Supervision (1988). International Convergence of Capital Measurement and Capital Standards. July.

Basel Committee on Banking Supervision (2004). International Convergence of Capital Measurement and Capital Standards. A revised framework. Bank for International Settlements, Basel, June.

Basel Committee on Banking Supervision (2006). International Convergence of Capital Measurement and Capital Standards. A revised framework. Comprehensive Version. Bank for International Settlements, June.

Basel Committee on Banking Supervision (2009). Basel II capital framework enhancements announced by the Basel Committee. BIS Press Release, 13 July, www.bis.org.

Basel Committee on Banking Supervision (2010). Basel III: A Global Regulatory Framework for More Resilient Banks and Banking Systems. December (modified version: June 2011).

Blum, J. (1999). Do capital adequacy requirements reduce risk in banking? Journal of Banking \& Finance, 23 (5).

Five years on from Lehman's: what have we learned? (2013). The Sloman Economics news site, September 15.

Hofbauer, G. (2008). Bankenkrise, Finanzkrise, Unternehmenskrise? In: Going Public. pp. 68-69.

Hofbauer, G. (2009). Rating. In: Impulse. pp. 90-92.

Hofbauer, G., Bergmann, S. (2008). Optimales Rating für KMU.

Hofbauer, G., Klimontowicz, M., Nocoń, A. (2016). Basel III Equity Requirements and a Contemporary Rating Approach. Copernican Journal of Finance \& Accounting, 5 (1). DOI: 10.12775/CJFA.2016.005.

Hofbauer, G., Král', M. (2015). Der Einfluss der Basel III Regularien auf Klein- und Mittelständische Unternehmen in Deutschland. In: G. Hofbauer und Kollegen (eds.), Challenges, Research and Perspectives (pp. 209-222). Berlin: uni-edition.

Hofbauer, G., Král', M., Seiler, P. (2015). Evidenzbasiertes Rating von Unternehmen und der Einfluss von marketing und Vertrieb im Lichte von Basel III. Arbeitsberichte - Working Papers, Technische Hochschule Ingolstadt, 35.

Hofbauer, G., Nocoń, A., Klimontowicz, M. (2016). The development of the Basel Framework and the Impact on Small and Medium-Sized Enterprises in Germany and Poland. Journal of Business and Economics, 5 (12). DOI: 10.15341/jbe(2155-7950)/03.07.2016/001.

Iwanicz-Drozdowska, M. (2012a). Bank's financial management. Warszawa: PTE.

Iwanicz-Drozdowska, M. (2012b). Banking risk management. Warszawa: Poltext.

Kopiński, A. (2008). Bank's financial analysis. Warszawa: PTE.

Marcinkowska, M. (2005). The evolution of banks' capital adequacy standards. In: P. Karpuś, J. Węcławski (eds). Transformation of financial market in Poland. Vol. I: Financial institutions and mechanisms of their operation. Lublin: UMCS Publishing House.

Marcinkowska, M. (2009). Banks' capital standards. The New Base Capital Accord in Polish supervisory regulations. Regan Press.

Marcinkowska, M. (2010). Basel's tortuous patos... or bank capital standards: yesterday, today, tomorrow. „Annales Universitatis Maria Curie-Skłodowska" Lublin, Vol. XLIV, 2, Sectio H.

Nocoń, A. (2015). Capital adequacy ratios in early warning system of modern central banks. In: Challenges, Research and Perspectives. Trust in social, economic and financial relations. G. Hofbauer und Kollegen (eds). European Research and Working Group, Berlin: Uni-edition GmbH.

Nocoń, A. (2016). The response system of modern central banks on banking system instability. Warszawa: Difin. 
Rojas-Suarez, L. (2001). Can International Capital Standards Strengthen Banks In Emerging Markets? Institute for International Economics Working Paper No. 01-10.

\section{Cytowanie}

Hofbauer, G., Nocoń, A., Klimontowicz, M. (2016). Development of equity regulations in the Basel framework. Współczesne Finanse. Teoria i Praktyka, 1 (1), 5-14. DOI: 10.18276/wf.2016.1-01. 